\title{
Człowiek i algorytm. Ku automatyzacji rozgrywki w grach crowdsourcingowych
}

Sonia Fizek 


\section{Szkice}

\section{Człowiek i algorytm. Ku automatyzacji rozgrywki w grach crowdsourcingowych}

Sonia Fizek

TEKSTY DRUGIE 2017, NR 3, S. 15-31

DOI: $10.18318 /$ td.2017.3.2

\section{Gra z maszyną?}

Nie ma nikogo innego na świecie.

W zasięgu wzroku nikt inny.

To byli jedyni, którzy mieli znaczenie.

Oni byli jedynymi, którzy zostali. ${ }^{2}$

Google

9 marca 2016 roku świat wstrzymał oddech na rekordowo długą chwilę w ponad 2500-letniej historii gry w go. Wszystko za sprawą zaplanowanej na siedem dni

1 Tytuł tej części jest nawiązaniem do książki Wyścig z maszyna (oryg. Race against the machine). A. McAfee, E. Brynjolfsson Race against the Machine. How the Digital Revolution is Accelerating Innovation, Driving Productivity, and Irreversibly Transforming Employment and the Economy, Digital Frontier Press, Lexington, MA 2011.

2 Fragment wiersza wygenerowanego przez algorytm Google’a w tłumaczeniu automatycznym Google'a (there is no one else in the world. / there is no one else in sight. / they were the only ones who mattered. / they were the only ones left.)
Sonia Fizek - dr, badaczka gier i mediów cyfrowych, adiunkt w School of Arts, Media and Computer Games w Abertay University of Dundee. Redaktor naczelna "Journal of Gaming and Virtual Worlds". Wybrana tematyka badawcza: automatyzacja w kontekście gier, algorytmiczne podmioty grające, gry ZPG, zależność pomiędzy pracą a zabawą, gamifikacja, ludyfikacja kultury, projektowanie gier. Publikacje: http:// abertay.academia. edu/SoniaFizek; Kontakt:s.fizek@ abertay.ac.uk; Twitter: @SFonic 
rozgrywki Google DeepMind Challenge z udziałem człowieka i maszyny pierwszej takiej od czasów pamiętnej bitwy szachowej między Garrim Kasparowem i sztuczną inteligencją Deep Blue, zorganizowanej w 1997 roku. Pochodzący z Korei Południowej Lee Sedol (pseud. Twardy Kamień), wicemistrz świata w go, podjął się wyczerpującego zadania rywalizacji z algorytmem AlphaGo, stworzonym przez naukowców firmy Deep Mind, należącej do Google'a. I po siedmiu dniach został pokonany, przegrywając cztery z pięciu partii.

Obserwując tego rodzaju przełomowe wydarzenia - a także śledząc postępy w udoskonalaniu sztucznej inteligencji i towarzyszące im entuzjastyczne reakcje - możemy odnieść wrażenie, że spod dominującego antropocentrycznego modelu myślenia wyłonił się już inny, który w centrum uwagi stawia algorytm. Z tej „algorycentrycznej”3 perspektywy rodzą się prognozy rychłej dominacji inteligentnych maszyn nad ludźmi. Być może zwycięstwo systemu AlphaGo okaże się kluczowym momentem w historii rywalizacji człowieka i maszyny, w której to ludzkość sama powołała do życia swojego przeciwnika. O ile jednak algorytm był w stanie pokonać człowieka w go, o tyle w innych typach gier wciąż pozostaje za nim daleko w tyle. Codziennie setki tysięcy graczy rozwiązują realne problemy i łamigłówki naukowe, poświęcając czas na gry crowdsourcingowe, takie jak EteRNA (2010). I okazują się niezastąpieni zarówno w projektowaniu struktur przestrzennych cząsteczek RNA, jak i w rozpoznawaniu, klasyfikowaniu i segregowaniu strzępów informacji w dziesiątkach podobnych zgamifikowanych projektów.

Warto zwrócić uwagę, że marzenie ludzkości o stworzeniu zautomatyzowanego odpowiednika ludzkiego gracza czy systemu zdolnego do samoregulacji narodziło się na długo przed erą cyfryzacji i sztucznych sieci neuronowych. Prawdopodobnie najbardziej znanym zachodnim przykładem tego typu jest Mechaniczny Turek, XVIII-wieczny „automatyczny” szachista, stworzony przez Wolfganga von Kempelena. Antropomorficzna figura naturalnych rozmiarów, obsługująca szachownicę mechanicznym ramieniem z systemem zegarowym, przez ponad 80 lat podróżowała po świecie, rozgrywając partie szachowe z ludźmi, w tym - jak głoszą legendy - z Napoleonem Bonaparte czy Benjaminem Franklinem.

Mechaniczny Turek otrzymał orientalizowaną postać czarnoksiężnika, podejmującego rywali szachowych przy solidnym drewnianym biurku, dzięki czemu publiczność odbierała go jako istotę tajemniczą - obcą ich

3 Jako przeciwieństwo perspektywy antropocentrycznej. 
doświadczeniu kulturowemu. O wyglądzie mechanicznego gracza nie zdecydowały wyłącznie względy estetyczne. Od czasów średniowiecza „zachodni świat chrześcijański utożsamiał maszyny ze światem Arabów, Greków i Mongołów, postrzegając je [...] jako wytwory obcej wiedzy i egzotycznych technik ${ }^{4}$. Z czasem wyszło jednak na jaw, że Turek von Kempelena to nie inteligentny robot o tajemniczym mechanizmie działania, a zwykła mistyfikacja oparta na iluzji. Przez lata rywale szachowi mierzyli się nie z maszyną, lecz z człowiekiem, który sprytnie ukryty w drewnianym biurku, sterował ramieniem Turka - co pozwala o nim myśleć jako o ludzko-mechanicznym Deleuzjańskim asamblażu. Mimo rozczarowującej prawdy o Mechanicznym Turku należy go uznać za doskonałą egzemplifikację ludzkiej fantazji o stworzeniu automatycznego gracza czy też inteligentnej maszyny, zdolnej do odtwarzania ludzkich procesów poznawczych.

\section{Automatyzacja gier i rozgrywki}

Dziśs, u progu nowej ery cyfrowej, zagadnienie automatyzacji cieszy się olbrzymim zainteresowaniem społecznym, budząc - jak dawniej - tyleż samo ciekawości, co obaw. Wywiera ono wpływ na niemal każdy obszar naszego życia, a w szczególności wykonywanej przez nas pracy, jak i produkcji przedmiotów codziennego użytku oraz wdrażanych innowacji, odzwierciedlających wartości czwartej rewolucji przemysłowej. Wśród najbardziej oczywistych przykładów znajdą się całkowicie zautomatyzowane „inteligentne” fabryki Tesli, autonomiczny samochód Google'a, zmechanizowana obsługa zamówień i łańcuchów dostaw firmy Amazon, a także mnóstwo innych podobnych przedsięwzięć. Także w dziedzinie twórczości artystycznej wzrasta rola automatyzacji, choć warto pamiętać, że pierwsze przykłady wygenerowanych komputerowo dzieł plastycznych, poetyckich czy muzycznych pochodzą sprzed kilku dekad - czyli są niewiele młodsze od samych komputerów a szczyt ich popularności przypada na lata 6o. XX wieku' . Dzisiejsze czasy

4 E.R. Truitt Medieval Robots. Mechanism, Magic, Nature and Art, University of Pennsylvania Press, Pittsburgh 2015, S. 19.

5 G. Deleuze, F. Guattari A Thousand Plateaus. Capitalism and Schizophrenia, trans. by B. Massumi, The University of Minnesota Press, Minneapolis-London 1980/1987.

6 F. Nake There should be no computer art, "Bulletin of the Computer Arts Society”, University of London, Birkbeck 1971, s. 18-21, http://www.bbk.ac.uk/hosted/cache/archive/PAGE/PAGE18. pdf(17.05.2017). 
dostarczają wielu barwnych przykładów automatyzacji sztuki. Wytwórnia Sony planuje wydanie pierwszego w historii albumu muzycznego w całości stworzonego przez sztuczną inteligencję. Na zamówienie agencji J. Walter Thompson w Amsterdamie powstał Nowy Rembrandt (The Next Rembrandt), dzieło malarskie „stworzone” na drukarce 3D przez algorytm uczenia głębokiego. Także firma Google eksperymentuje ze sztuczną inteligencją, która uczy się języka naturalnego z ogromnego zasobu romansów, by w kolejnym kroku wyprodukować wersy - terminologia przemysłowa nie jest tu dziełem przypadku - które ludzkiemu czytelnikowi będą przypominać poezję.

Nie będzie dla nikogo niespodzianką, że automatyzacja nabiera jeszcze większego znaczenia w dziedzinie gier. Dwa wymienione we wstępie przykłady - Deep Mind Challenge i EteRNA - stanowią jedynie czubek ludycznej góry lodowej. System AlphaGo to dowód na zdolność algorytmów do stawienia czoła ludzkiemu graczowi oraz postępującej inteligencji maszyn. Algorytmy w grach crowdsourcingowych - zasadniczy przedmiot tego artykułu - graja „ramię w ramię” z człowiekiem, czerpiąc wiedzę z jego zachowań.

Inne przykłady obejmują półautomatyczne gatunki gier lub przypadki automatyzacji określonych działań w grze, w których część zadań rozwiązuje algorytm. Można tu wymienić m.in. zjawisko „bottingu”, czyli wykorzystania botów i makr w grach typu MMORPG (Massively Multiplayer Online Role-Playing Game), umożliwiającego automatyzację fragmentów rozgrywki, „wyręczanie” gracza przez sztuczną inteligencję oraz uwalnianie go od monotonnego powtarzania trudniejszych zadań, niezbędnych do osiągnięcia wyższych poziomów ${ }^{8}$. W przypadku gier polegających głównie na mechanicznym „klikaniu” (incremental games, indle games), takich jak Automatic RPG (2015) czy AdVenture Capitalist (2015), zautomatyzowany proces grania kreuje nowy model rozrywki, w której rozwijanie bohaterów i nabieranie doświadczenia dokonuje się półautomatycznie, a rola gracza sprowadza się do „zarządzania” postacią.

Podobnie jak w przypadku kreowanej przez algorytmy poezji i sztuki, zjawisko automatyzacji ma także wpływ na proces projektowania gier. Zautomatyzowane systemy ich tworzenia, zdolne do tworzenia abstrakcyjnych

7 S. Gibbs Google Al project writes poetry which could make a Vogon proud, "The Guardian" 17.05.2017, https://www.theguardian.com/technology/2016/may/17/googles-ai-write-poetry-stark-dramatic-vogons (17.05.2017).

8 S. de Paoli Automatic Play and Player Deskilling in MMORPGs, "Game Studies" 2013 No. 13 (1), http://gamestudies.org/1301/articles/depaoli_automatic_play. 
reguł oraz ich wizualnej realizacji ${ }^{9}$, jak również zautomatyzowane szkicowanie pomysłów ${ }^{10}$ są przedmiotem badań informatyki kreatywnej (creative computing).

Dla lepszego zilustrowania tego fenomenu stosuję termin „automatyzacji rozgrywki", obejmujący zarówno rozmaite gatunki gier półautomatycznych, jak i scenariusze oraz modele projektowania gier, w których stosuje się zasady automatyzacji. Taka różnorodność przykładów wymaga dogłębnej analizy. Choć zarówno gry z gatunku idle games, jak i automatycznie projektowane systemy, zjawisko rywalizacji człowieka z algorytmem czy gry crowdsourcingowe reprezentują ten sam fenomen kulturowy, istnieją między nimi zasadnicze różnice. W artykule tym skoncentruję się na ostatnim $\mathrm{z}$ wymienionych przykładów, ze szczególnym uwzględnieniem gry EteRNA (2010). Podejmę próbę opisu i analizy gier crowdsourcingowych z perspektywy zagadnienia automatyzacji oraz rywalizacji i współpracy między człowiekiem i maszyną.

Koncentracja na grach crowdsourcingowych pozwoli na zakreślenie szerszej perspektywy poznawczej oraz postawienie pytania o istotę relacji człowiek - maszyna - algorytm, niezwykle ważnego w dobie automatyzacji. Czy samodzielne algorytmy sprawią, że człowiek stanie się istotą zbyt "przestarzałą" do podjęcia walki z maszyną, czy też możliwa jest jakakolwiek forma symbiozy i odpowiedzialnego współuczestniczenia maszyn w naszej codzienności? A może pytanie o zastępowanie jednej formy bytu inną zupełnie nie ma sensu, a nasza uwaga powinna skupić się głównie na zagadnieniu społecznej odpowiedzialności za procesy automatyzacji?

\section{Chimery naszych czasów"}

Według słów historyka nauki „,bez względu na epokę maszyna stanowi potężny symbol ludzkiego pojmowania natury", pozwala określić, czym jest

9 M.J. Nelson, M. Mateas Towards Automated Game Design, publikacja pokonferencyjna The 10th Congress of the Italian Association for Artificial Intelligence, Heidelberg: Springer-Verlag, Berlin 2007, https://games.soe.ucsc.edu/sites/default/files/Nelson_Mateas_-_Automated_ Game_Design_-_AllA07.pdf (17.05.2017).

M.T. Llano, M. Cook, Ch. Guckelsberger, et al. Towards the Automatic Generation of Fictional Ideas for Games, Computational Creativity Research Group, Goldsmiths University of London 2014, http://ccg.doc.gold.ac.uk/papers/llano_exag14.pdf (17.05.2017).

D. Haraway A Cyborg Manifesto. Science, technology, and socialist-feminism in the late twentieth century, przeł. E. Franus, „Magazyn Sztuki” 1998 nr 17, http://magazynsztuki.eu/old/archiwum/ post_modern/postmodern_9.htm (17.05.2017). 
naturalność i sztuczność, oraz określa miejsce człowieka we Wszechświe$\mathrm{cie}^{12}$. Dla przykładu postać Mechanicznego Turka odzwierciedla dążenie do „naśladowania i poszerzania granic ludzkiego intelektu, co od zawsze stanowiło najważniejszy aspekt wszelkich koncepcji związanych z mechanizacją umysłu, rozwijanych przez wybitnych myślicieli, jak Pascal, Leibniz, Babbage, Wiener czy Turing ${ }^{13}$.

Automaty, a także całkowicie lub półautonomiczne maszyny zdolne do naśladowania różnych czynności (poruszania się, śpiewania, pisania czy grania) interesowały ludzkość od tysięcy lat, czego ślady znajdziemy już w starożytności. Hydrauliczne, pneumatyczne, mechaniczne, elektryczne czy cyfrowe ${ }^{14}$ - wszystkie one niosły ze sobą obietnicę doścignięcia, a nawet przewyższenia człowieka.

Procesy automatyzacji, szczególnie w obszarach kognitywnych, prowadzą w następstwie do postawienia pytania o relację ludzi, maszyn i samouczących się algorytmów. Związek ten od zawsze cechowała ambiwalencja. W czasach poprzedzających epokę cyfrową, określano go m.in. jako symbiozę i partnerską wymianę $^{15}$, wyścig i rywalizację „sztucznych i naturalnych automatów"16 bądź też jako jednostronną relację przedłużenia lub wzmocnienia, zgodnie z którą fizyczne i umysłowe zdolności człowieka są udoskonalane przy udziale maszyn ${ }^{\mathbf{1 7}}$.

Wszystkie wymienione powyżej perspektywy, z których opisuje się relację człowiek - maszyna, prowadzą do lat 6o. XX wieku - dekady, która zrodziła ożywioną i zróżnicowaną refleksję nad cybernetyką. Pierwsza, o której warto wspomnieć, wiąże się z postacią Josepha Carla Robnetta Licklidera, jednego z następców Norberta Wienera. Pracował on nad sieciami cyfrowymi w należącej do Pentagonu Agencji Zaawansowanych Projektów Badawczych

12 E.R. Truitt Medieval Robots..., S. 3.

13 A. Aytes Cognitive Labour, Crowdsourcing, and Cultural History of the Mechanisation of the Mind, "Leonardo Electronic Almanac" 2011 No. 17 (1), http://ojs.gold.ac.uk/index.php/lea/article/ view/199/146 (15.03.2017). M. de Valk A contemporary Delphic Oracle: the church of big data, „Furtherfield” 2016 http://furtherfield.org/features/contemporary-delphic-oracle-church-big-data (20.04.2017). I.C.R. Licklider Man-Computer Symbiosis. IRE Transactions on Human Factors in Electronics, 1960 HFE-1, s. 4-11. J. von Neumann Theory of Self-Reproducing Automata, trans. A.W. Burks, University of Illinois Press, Urbana-London 1966. M. McLuhan Understanding Media: The Extensions of Man, The MIT Press, Cambridge, MA 1964/1994. 
(ARPA) i porównał relację człowieka i maszyny do specyficznej symbiozy, jaka zachodzi między drzewem figowym i osą figową:

Drzewo i owada łączy całkowita wzajemna zależność: drzewo nie może się rozmnażać bez owada; owad nie może się wyżywić bez drzewa; wspólnie wypracowały one nie tylko korzystny, ale i produktywny oraz piękny układ. To oparte na kooperacji „wspólne życie w bliskim związku, czy wręcz zespolenie dwóch odmiennych organizmów" nazywane jest symbiozą. ${ }^{18}$

Cybernetyczne fantazje na temat "międzygatunkowych hybryd" ${ }^{19}$ nie były domeną samego tylko Wienera, głoszącego, że człowiek i maszyna mogą koegzystować i współpracować, zamiast walczyć ze sobą o dominację. $\mathrm{Na}$ przykład John von Neumann przewidział powstanie samoreprodukujących się maszyn, zaprogramowanych do konstruowania samych siebie bez udziału człowieka ${ }^{20}$. Stanisław Ulam, przyjaciel i współpracownik Neumanna, w poświęconym mu pośmiertnym hołdzie wspomniał ich dawną rozmowę o: „stale przyśpieszającym rozwoju technologii i zmianach w stylu naszego życia oraz wrażeniu osiągania przez nas takiego osobliwego punktu w historii wyścigu z maszynami, po przekroczeniu którego stosunki międzyludzkie już nigdy nie będą mogły wyglądać tak jak przedtem"21.

Fascynacja maszynami i sztuczną inteligencją oraz przeświadczenie o ich nieprzeciętnym potencjale to domena nie tylko matematyków, ale także teoretyków mediów. Na przykład Marshall McLuhan niemal w jednym czasie zgłębiał problem mediów, maszyn i technologii, pojmowanych przez niego jako „rozszerzenie naszych własnych systemów biologicznych i układów nerwowych, prowadzące do zwiększenia mocy i prędkości"22.

18 J.C.R. Licklider Man-Computer Symbiosis..., s. 4-11.

19 N. Dyer-Witheford Cyber-Proletariat. Global Labour in the Digital Vortex, University of Chicago Press, Chicago 2015. J. von Neumann Theory of Self-Reproducing Automata... S. Ulam, John von Neumann 1903-1957, „Bulletin of the American Mathematical Society" 1958 No. 64 (3).

M. McLuhan Understanding Media... Co ciekawe, technologię i automatyzację interpretowano w kategoriach rozszerzenia potencjału człowieka także w słynnym cyklu wykładów "The Reith Lecture" Radia BBC: Sir L. Bagrit The Age of Automation. The BBC Reith Lectures, Weidenfeld and Nicolson, London 1964. 
Choć cybernetyka nie koncentrowała się wyłącznie i od razu na zastępowaniu człowieka maszyną oraz projektach łączenia obu organizmów w symbiotycznym uścisku, opartym na hybrydyzacji, przekonanie o możliwej symbiozie maszyny i człowieka okazało się jedynie momentem przejściowym. Rozwijając swoją metaforę drzewa figowego, Licklider przyznał, że maszyny mogą potencjalnie przewyższyć umysł człowieka i zdominować przyszłość.

W latach 8o. i 9o. ta „cudownie odrażająca”23 fantazja o połączeniu człowieka z maszyną zyskała silny wydźwięk polityczny, który nie tylko wykroczył poza ramy perspektywy technocentrycznej i upojenia myślą o wzrastającej potędze maszyn, ale co ważniejsze, naruszył tradycyjny zachodni porządek ujmowania tematu wyłącznie z pozycji białego mężczyzny. W swoim kultowym już Manifeście Cyborga Donna Haraway postawiła odważną tezę, że wszyscy jesteśmy cyborgami - hybrydą organizmu i maszyny, wywołując wielowątkową dyskusję społeczno-polityczną. Zwróciła uwagę, że:

W tradycji „zachodniej” nauki i polityki - tradycji rasistowskiego, zdominowanego przez mężczyzn kapitalizmu, tradycji postępu i przywłaszczenia natury jako środka służącego do tworzenia kultury, tradycji reprodukcji własnego „ja” przez jego lustrzane odbicie w Innym - relacje między organizmem a maszyną określała wojna o linie podziału. Stawką tego przygranicznego konfliktu były obszary produkcji, rozmnażania i wyobraźni. ${ }^{24}$

Cyborgi, mechanizmy rozszerzające możliwości człowieka oraz wszelkie inne formy, zarówno symbiotycznych, jak i pasożytniczych relacji ludzi z maszynami są czymś więcej niż tylko figurą retoryczną. Pokazują one, jak różne drogi może obrać technologia, wkraczając w nasze życie, a w rezultacie kształtując świadomość społeczną. Różnorodność koncepcji, określających koegzystencję człowieka i maszyny uświadamia nam ich wagę w wymiarze polityczno-społecznym. Cyborg nie jest bytem zawieszonym w naukowej próżni i, jak zauważa Haraway, zajmuje miejsce w określonej tradycji i bardzo konkretnej rzeczywistości społecznej. Stąd tak ważne jest zachowanie postawy sceptycznej wobec utopii, które „w naiwny sposób umieszczają technologię i myślenie

23 W. Chun UO Today: Wendy Chun, Oregon Humanities Centre, 2016 https://www.youtube.com/ watch? $v=r Z Y F--a Q m r Y(22.05 .2017)$. 
cybernetyczne poza kontekstem władzy i jej porządku", jak i uniknięcie całkowicie dystopicznych stanowisk „opartych na błędnym przeświadczeniu o pełnej integralności każdej istoty, ignorującym fakt istnienia bytów ludzkich kształtowanych przez pozaludzkie narzędzia i mechanizmy"25.

Tytułowe współczesne „chimery” naszych czasów przyjmują rozmaite kształty - od autonomicznych pojazdów i wielozadaniowych robotów typu Baxter przez niezależne algorytmy zdolne do podjęcia gry z człowiekiem, aż po gry crowdsourcingowe. Wszystkie one wyzywają na pojedynek, dopełniają lub zastępują człowieka - na różne sposoby i w określonych kontekstach. Ostatni z przykładów reprezentuje szczególny rodzaj „chimery” - to połączona siecią, ludyczna hybryda człowieka, maszyny i algorytmu, która będzie przedmiotem dalszej części tego artykułu.

\section{Człowiek i algorytm w grach crowdsourcingowych}

Gry crowdsourcingowe (crowd - tłum, sourcing - pozyskiwanie) określane są również jako citizen science games (gry nauki obywatelskiej), human-based computation games (gry obliczeniowe oparte na zdolnościach ludzkich), games with a purpose lub GWAP (gry z celem; pożyteczne gry) oraz knowledge games (gry naukowe) ${ }^{26}$. Jest to stosunkowo młode zjawisko w świecie gier - jego rozwój przypada na ostatnią dekadę. Gry te mogą być postrzegane jako dynamiczne systemy obliczeniowe lub przetwarzające dane, przyciągające ludzi gotowych do rozwiązywania konkretnych problemów ${ }^{27}$ albo jako współdzielona przestrzeń zabawy, w której gracze na drodze współpracy osiągają cele wykraczające poza świat samej gry ${ }^{28}$. Można również położyć tu nacisk na akt zespolenia człowieka, algorytmu i maszyny w jednym działaniu, w którym gracz rozwiązuje zadania kognitywne, a algorytm uczy się

25 A. Franke, S. Hankey, M. Tuszynski Nervous Systems: Quantified Self and the Social Question, Spector Books, Lipsk 2016.

K. Schrier Knowledge Games. How Playing Games Can Solve Problems, Create Insight, and Make Change, Johns Hopkins University Press, Baltimore 2016.

Tamże.

S. Fizek All Work, no Play. Are games becoming the factories of the future?, „First Person Scholar", University of Waterloo, The Games Institute 2016, http://www.firstpersonscholar.com/ all-work-and-no-play (20.04.2017). A. Dippel, S. Fizek Laborious Playgrounds: Citizen science games as new modes of work/play in the digital age, w: The Playful Citizen: Knowledge, Creativity, Power, ed. by R. Glas, S. Lammes, M. de Lange, J. Raessens, I. de Vries, Amsterdam University Press, Amsterdam 2018 (w przygotowaniu). 
schematów ludzkich zachowań w dostępnych ramach wieloosobowej gry sieciowej, uruchomionej jednocześnie na tysiącach połączonych ze sobą komputerów.

Operując na dużych zbiorach danych, udostępnionych w tej współdzielonej przestrzeni ludycznej, gracze rozwiązują łamigłówki, a także rozpoznają, klasyfikują i segregują informacje. Wszystko po to, by wesprzeć naukowców i badaczy w ich pracy, obejmującej rozmaite dziedziny: od biologii i neurobiologii przez astronomię po historię sztuki i wiele innych. Gracze modelują sekwencje RNA (EteRNA), identyfikują komórki rakowe (Reverse the Odds), tworzą mapy połączeń neuronowych w mózgu (EyeWire), klasyfikują galaktyki (Galaxy Challenge) czy pomagają w katalogowaniu dzieł sztuki (ARTigo).

W ostatnich latach okazało się, że oparte na współpracy gry i wyzwania $\mathrm{z}$ dużymi zbiorami danych są wyjątkowo skutecznym narzędziem naukowym, o czym świadczy fakt uruchamiania odrębnych, przeznaczonych dla nich platform internetowych, jak Kaggle, Zooniverse czy Metadata Games. Instytucje naukowe i centra badawcze mogą tworzyć tutaj gry, angażujące badaczy-amatorów z całego świata.

Jedną z pierwszych gier z dziedziny tzw. citizen science games była FoldIT (2008 Solve Puzzles for Science), czyli wyzwanie internetowe polegające na modelowaniu molekularnym białek. FoldIT był pomyślany jako interaktywna kontynuacja projektu Rosetta@Home (2005). O ile jednak pierwowzór korzystał z mocy obliczeniowej połączonych w sieć komputerów z całego świata, FoldIT rozwinął pomysł w nowym kierunku. W rozwiązywanie realnych problemów z dziedziny biologii zaangażował "zwykłych" ludzi, oferując im zabawę naukową. Ogromny sukces badawczy tego internetowego laboratorium zainspirował innych. Tak narodził się m.in. ogólnoświatowy projekt EteRNA (2010, Make Molecules, Advance Science), w którym dziś uczestniczy ponad 38000 badaczy-amatorów.

Sama gra przypomina dwuwymiarową układankę, w której gracze projektują struktury, mając do dyspozycji cztery typy elementów wchodzących w skład RNA (kwasu rybonukleinowego): adeninę, guaninę, uracyl i cytozynę, oznaczonych w grze kolorami (odpowiednio, żółtym, czerwonym, niebieskim i zielonym).

Rozgrywka w EteRNA opiera się na pokonywaniu kolejnych poziomów. Gracz rozwiązuje coraz trudniejsze zadania i oczekuje na wyniki, obserwując animowaną symulację procesów chemicznych. Mamy więc do czynienia z klasycznym stopniowaniem napięcia, które ulega rozładowaniu 
w chwili uzyskania przez gracza informacji zwrotnej o pomyślnym ukończeniu ćwiczenia. To moment jego małego „zwycięstwa”. Osiągnięcia naukowe, mierzone obiektywnym systemem punktowym, dają graczowi poczucie satysfakcji.

Innych graczy zainteresowanych projektami typu EteRNA może motywować świadomość uczestnictwa w czymś więcej niż zwykła gra. Naukowcy doceniają obywatelski wysiłek badaczy-amatorów (bada[gra]czy) - ich najlepsze wirtualne projekty są klasyfikowane, analizowane i wreszcie syntetyzowane w prawdziwych laboratoriach na Uniwersytecie Stanforda, a autorów wymienia się w artykułach i opracowaniach akademickich. Wrażenie realnej sprawczości, przyjemność płynąca z zabawy o doniosłym znaczeniu społecznym, elementy rywalizacji i współpracy w dużym środowisku internetowym czy też poczucie przynależności do środowiska naukowego leżą u podstaw wszystkich gier typu citizen science.

Uczestnicy gry są motywowani i nagradzani przez system na każdym poziomie zaawansowania - otrzymują do rozwiązania coraz bardziej skomplikowane zadania, zbierają punkty i odznaki, dzięki tablicom z wynikami osiągają wyższy status w społeczności graczy, aż wreszcie zyskują uznanie w środowisku naukowym.

Inaczej niż jego poprzednicy (Rosetta@Home i FoldIT) projekt EteRNA włącza w sieć komputerową czynnik ludzki, działając dwutorowo - przekazuje człowiekowi zadania do rozwiązania, a jednocześnie rozwija algorytm (EteRNABot), który uczy się od człowieka. Bot jest „karmiony” danymi na temat wzorów strukturalnych generowanych przez człowieka, a następnie selekcjonuje najbardziej skuteczne strategie działania (Lee et al. oraz uczestnicy projektu EteRNA 2013). W takim sieciowym laboratorium każda ze stron - człowiek i algorytm - ma swoje odrębne zadania, które wzajemnie się uzupełniają, w myśl koncepcji Licklidera. Czy taka symbioza ma szansę się utrzymać, czy czeka nas w przyszłości nierówna gra pod dyktando "mądrzejszego" algorytmu?

\section{Na krawędzi przedawnienia}

Do tej pory człowiek górował nad maszynami w rozwiązywaniu łamigłówek i przewidywaniu wzorów, co jest podstawą rozgrywki w grach crowdsourcingowych. Są jednak i tacy, którzy twierdzą, że niezrównany potencjał ludzkiego umysłu może zostać wkrótce zastąpiony przez algorytm, taki jaki EteRNABot, który już teraz osiąga daleko idące postępy. Dziennikarze roztaczają czarne 
wizje na temat gier przyszłości, w których ludzie nie rywalizują już między sobą ani nawet z maszynami, ale są na ich usługach jako "gromadzący informacje niewolnicy" uwięzieni w fabryce rozrywki, sterowanej cyfrowym umysłem $^{29}$. Zdolna do uczenia się i grania maszyna cyfrowa budzi strach, który zrodziła rewolucja przemysłowa, a epoka automatyzacji w obszarze zadań poznawczych jeszcze go nasiliła, budząc do życia demony przeszłości - prognozy zastąpienia ludzkiej siły roboczej bardziej wydajną maszyną. Fakt, że w świecie rozrywki cyfrowej maszyny przestały być jedynie narzędziami w rękach człowieka, a weszły w rolę anonimowych graczy „zaludniających” ten świat, budzi głęboki niepokój.

Pełna automatyzacja rozgrywki w grach crowdsourcingowych może doprowadzić do upadku całej idei. Projekty te powstają przecież w konkretnym celu o znaczeniu społecznym, a ich modus operandi i mechanizmy grywalizacji służą głównie przyciągnięciu większej liczby ludzi oraz zachęceniu ich do aktywnego wspierania projektów naukowych. Pojawianie się i znikanie nowych gatunków gier nie jest oczywiście niczym wyjątkowym, bez względu na to, czy dokonuje się za sprawą automatyzacji rozgrywki, czy choćby zmian kulturowych. Istotna jest także umiejętność wykorzystania uczących się algorytmów do rozwijania nauki oraz przyspieszania procesu generowania wiedzy, tak aby nie musiał się on opierać wyłącznie na długotrwałym i żmudnym gromadzeniu i selekcjonowaniu danych. Zarazem jednak dominacja algorytmu może położyć kres wieloletniej tradycji nauki obywatelskiej.

W ten sposób pojmowana automatyzacja wywołuje obawy o to, że maszyna może zastąpić człowieka, oraz podtrzymuje tradycję postrzegania relacji człowiek - automat w kategoriach opozycji binarnych. Takie obawy są silnie zakorzenione w dawnym modelu współpracy człowieka z maszyną, w którym rolą człowieka jest nadzorowanie maszyny, a rolą maszyny jest posłuszne wykonywanie ludzkich poleceń. Jednakże współczesne czasy naznaczone wszechobecnością coraz doskonalszych maszyn wymagają od nas zweryfikowania tego tradycyjnego podejścia. Być może rozwiązaniem jest całkowite odejście od perspektywy antropocentrycznej i potraktowanie tandemu człowiek-maszyna jako elementu, który nierozerwalnie współtworzy cyfrowy „pejzaż”. Żadna ze stron nie znajduje się tutaj w pozycji uprzywilejowanej, natomiast obie - jak postulował niemiecki teoretyk mediów Friedrich Kittler - zachowują autonomię: „maszyny i ludzie integrują się nie po to, by jedno

29 B. Koerner New Video Game Let's Researchers Mess with RNA, "Wired", 5.07.2012, http://www. wired.com/2012/o7/ff_rnagame (17.05.2017). 
mogło być substytutem drugiego, a na zasadzie współdziałających elementów większego systemu ${ }^{30}$.

Jeśli gry crowdsourcingowe potraktujemy jako przykład takiego właśnie systemu, będziemy mogli dostrzec, z jak fascynującym zjawiskiem mamy do czynienia. Hybryda człowieka, maszyny i algorytmu, skonstruowana tak, aby zadania i łamigłówki rozwiązywane przez człowieka mogły być jednocześnie polem treningowym dla algorytmu, uczącego się schematów ludzkich działań, a z drugiej strony w ten sposób, by człowiek poznawał zasady poruszania się w świecie gry zaprojektowanym z uwzględnieniem percepcji algorytmicznej. Dzięki temu człowiek (gracz) nie tylko generuje informacje, z których korzystają algorytmy, ale sam jest potem "generowany" przez dokładnie te same algorytmy, ponieważ „wprzęgnięcie w [narzucony przez algorytm] strumień procesów oraz tryby rozwiązywania zadań determinuje stopień efektywności [człowieka] i jego pracy"31. Wprawdzie Aytes odnosił się w swoim artykule do rozwiązań stosowanych przez algorytm Mechanicznego Turka firmy Amazon, ale bez trudu można przenieść jego spostrzeżenia na grunt gier crowdsourcingowych, gdzie modus operandi opiera się na podobnej zasadzie ścisłej współpracy człowieka i algorytmu.

Niewątpliwie może fascynować zdolność maszyn do podejmowania samodzielnych decyzji, pisania poezji, grania w go i szachy czy tworzenia dzieł sztuki. Ale tak samo jak „«sztuka wygenerowana przez komputer» nie funkcjonuje tak naprawdę w żadnym bardziej prowokacyjnym sensie niż «sztuka malarska» czy «sztuka fortepianowa»"32, podobnie i gracz algorytmiczny nie funkcjonuje poza ludzkim kontekstem:

Algorytm napisał człowiek, korzystając z podstawy teoretycznej wymyślonej przez człowieka, na komputerze, który skonstruował człowiek, stosując specyfikację ułożoną przez człowieka, używając materiałów zgromadzonych przez człowieka, w firmie zatrudniającej ludzi, sięgając po narzędzia wykonane przez człowieka, i tak dalej. Sztuka tworzona przez komputer jest tworzona przez człowieka. ${ }^{33}$

B.N.M. Hansen Symbolizing Time: Kittler and Twenty-First-Century Media, w: Kittler Now. Current Perspectives in Kittler Studies, ed. by S. Sale, L. Salisbury, Polity Press, Cambridge 2015, S. 224. A. Aytes Cognitive Labour..., s. 125.

O. Roeder There is no difference between computer art and human art, "Aeon" 20.07.2016, https:// aeon.co/ideas/there-is-no-such-thing-as-computer-art-it-s-all-just-art (17.05.2017).

Tamże. 
We wszystkich wymienionych tu przypadkach ludzie są częścią zautomatyzowanego procesu, zarówno jako autorzy algorytmu, jak i jego odbiorcy, którzy obserwują grę stworzoną przez tandem człowiek-algorytm lub w niej uczestniczą. Jak na ironię właśnie takie „automatyczne” wynalazki jak Mechaniczny Turek udowadniają, że za każdą „magiczną” maszyną stoi człowiek, czy to dosłownie, poruszając elementami mechanizmu, czy pośrednio, ucząc sztuczną inteligencję.

W świetle powyższych konstatacji, obawa o to, że ludzki umysł okaże się zbyt przestarzały, wydaje się nie tak istotna, jak pytanie o nowy porządek społeczny. Niezawodowi bada[gra]cze, uczestniczący w projektach z obszaru citizen science mogą w przyszłości zostać zastąpieni przez algorytmy, ale z pewnością wyspecjalizowani naukowcy nadal będą pociągać za sznurki algorytmu.

\section{Uwagi końcowe - polityka automatyzacji}

Społeczeństwo nie może pozbyć się ciężaru decydowania o swych losach, wyzbywając się tej wolności na rzecz regulatora cybernetycznego. ${ }^{34}$

Stanisław Lem

WXVIII wieku Mechaniczny Turek stał się uosobieniem ówczesnej debaty filozoficznej - Kartezjańskiego dualizmu psychofizycznego ${ }^{35}$. Zaprezentowane przeze mnie algorytmiczne podmioty grające ilustrują z kolei trwającą obecnie dyskusję na temat automatyzacji wielu dziedzin życia oraz związanych z nią konsekwencji natury etycznej i polityczno-społecznej. Nadejście ery algorytmów uczenia głębokiego jest wydarzeniem o znaczeniu wykraczającym daleko poza planszę go czy środowisko gier crowdsourcingowych. AlphaGo „pobierał lekcje” od 100 tys. graczy-amatorów, przetwarzając różne scenariusze rozgrywki 30 milionów razy i stając się przy tym coraz wytrawniejszym graczem ${ }^{36}$. Jest on jednak algorytmem wielozadaniowym, co prawda testowanym w kontekście gry w go, ale rozwijanym z myślą o innych zastosowaniach.

34

35

36

S. Lem Summa Technologiae, Wydawnictwo Literackie, Kraków 1964.

A. Aytes Cognitive Labour..., s. 119.

BBC Newsnight AlphaGo and the future of Artificial Intelligence, https://www.youtube.com/ watch?v=53YLZBSSocc (20.04.2017). 
„Inteligencja” graczy algorytmicznych i wielozadaniowych algorytmów może budzić w nas strach przed rychłą dominacją maszyn oraz prowadzić do postrzegania automatyzacji jako takiej i automatyzacji rozgrywki w negatywnym świetle. Lecz koegzystencja maszyn i ludzi nie musi podlegać wyłącznie fatalistycznym interpretacjom. Nie oznacza to, że droga naiwnej utopii jest słuszniejsza. Te dwa ekstrema - nader pesymistyczne lub zbyt optymistyczne - zostały zakwestionowane m.in. przez kuratorów wystawy Systemy nerwowe. Kwantyfikacja a pytanie społeczne (Nervous Systems. Quantified Self and the Social Question):

zarówno utopijne jak i dystopijne postawy wprowadzają dezorientację. Albo naiwnie stawiają technologię i myśl cybernetyczną ponad strukturami władzy, albo opierają się na fałszywych i romantycznych założeniach o integralności niezależnej istoty ludzkiej. A przecież człowiek nigdy nie istniał w odrębności od narzędzi i maszyn. ${ }^{37}$

Automatyzacja nie jest kwestią przeznaczenia, lecz świadomej decyzji podjętej w konkretnym momencie i kontekście. Dobrym przykładem jest tutaj reakcja firmy Blizzard na wykorzystywanie przez graczy nielegalnych botów, automatyzujących części rozgrywki w World of Warcraft:

Podjęliśmy kroki przeciwko graczom World of Warcraft, którzy korzystali z programów, tzw. botów, odpowiedzialnych za automatyzację rozgrywki. Zależy nam na zachowaniu zasad fair play wobec każdego gracza World of Warcraft. Będziemy reagować na naruszenia wszelkich warunków korzystania z gry. Nie tolerujemy jakiejkolwiek formy oszustwa. ${ }^{38}$

W rozumieniu firmy Blizzard wykorzystywanie botów do automatyzacji rozgrywki prowadzi do nierównego współzawodnictwa. Lecz zasada fair play nie zawsze wykracza poza „magiczny krąg”39. Być może życie nie jest grą i nie musi być sprawiedliwe wobec każdego? Takie założenie wydaje się podstawą wielu debat na temat automatyzacji wprowadzanej w imię technologicznego

\footnotetext{
A. Franke, S. Hankey, M. Tuszynski Nervous Systems...

Blizzard Recent actions against botting in WoW, 13.05.2015, http://us.battle.net/forums/en/ wow/topic/17347095985 (15.03.2017).

J. Huizinga Homo Ludens: A Study of the Play-Element in Culture, Beacon Press, Boston, MA 1938/1992, s. 10.
} 
postępu. Jak prognozują ekonomiści, w ciągu dwóch najbliższych dekad utracimy nawet do 40 procent miejsc pracy na rzecz zautomatyzowanych maszyn i algorytmów ${ }^{40}$.

Podobnie jak w przypadku botów i zautomatyzowanych makr w grach typu MMORPG (Massively Multiplayer Online Role-Playing Game), automatyzacja w miejscu pracy dotyczy przede wszystkim powtarzalnych czynności. Podczas gdy Blizzard potępia wykorzystywanie botów w grze, korporacje i rządy najwyraźniej reprezentują inną postawę wobec automatyzacji przemysłu i codzienności. Jest ona kojarzona głównie z postępem, wzrostem efektywności pracy i wydłużeniem wolnego czasu dla dotychczas zapracowanych pracowników.

Co ulegnie zmianie, jeśli zaczniemy automatyzować rozrywkę jako taką? W niektórych grach nie tylko powtarzalne i żmudne części rozgrywki są przejmowane przez boty i makra. W przypadku tzw. gier „idle”, gier samo-grających (self-playing games) lub gier ZPG (zero-player games) ${ }^{41}$ niemalże cała rozgrywka odbywa się niezależnie od poczynań gracza. Cookie Clicker, Adventura Capitalist czy ADark Room - to tylko niektóre z tytułów, sprowadzających gracza do roli obserwatora świata gry, który może rozwijać się bez jego ingerencji. Być może automatyzacja rozgrywki zapoczątkuje nową formę aktywności ludycznej, opartą nie tyle na partycypacji i interakcji, co na obserwacji i interpasywnym delegowaniu zadań ${ }^{42}$ ?

Powyższe rozmaite przejawy automatyzacji rozgrywki wykraczają daleko poza „plac zabaw”. Gry, w które gramy, obnażają nasze systemy wartości i reguły, wedle których gramy. Systemy ludyczne reprezentują w mikroskali różnorodne modele koegzystencji człowieka i maszyny: te bardziej symbiotyczne w przypadku gier crowdsourcingowych i te oparte na zaciekłej rywalizacji, jak mecz AlphaGo. Oświadczenie firmy Blizzard również otwiera pole do ważnej dyskusji - mimo technologicznej możliwości stosowania botów wydawca decyduje się na całkowity zakaz ich rozprzestrzeniania w świecie gry. Gry „idle” z kolei przekształcają się w zautomatyzowaną formę rozrywki.

40 B.C. Frey, A.M. Osborne The future of employment: how susceptible are jobs to computerisation, 2013, http://www.oxfordmartin.ox.ac.uk/downloads/academic/The_Future_of_Employment.pdf (20.04.2017).

S. Björk, J.Juul Zero-Player Games: Or what we talk about when we talk about player, Philosophy of Computer Games Conference, Madrid 2012. 
Wszystkie te przykłady pokazująjak różnie można postrzegać i interpretować problem automatyzacji.

Może zatem zamiast pytać o to, czy maszyna lub algorytm zastąpią człowieka, powinniśmy skupić się na budowaniu nowych modeli współegzystencji, pytając o to, na jakich zasadach i w jakiej rzeczywistości społeczno-politycznej przyjdzie nam żyć? ${ }^{43}$ Lub też, parafrazując Haraway, na ile odpowiedzialnie będziemy budować zależności między tym, co organiczne i mechaniczne, oraz w jaki sposób przekształcimy „wojny o linie podziału”44 w obszary pokojowej negocjacji?

Przełożyła Monika Wasilewska

\section{Abstract}

\section{Sonia Fizek}

ABERTAY UNIVERSITY OF DUNDEE

Towards the Automation of Play: Humans and Algorithms in Crowdsourcing Games

This paper provides an introduction to the emerging phenomenon of the automation of play. It discusses the roles of human and algorithmic players focusing on so-called crowdsourcing or citizen science games, in which thousands of human players perform various tasks to advance scientific research, and by doing so help train the algorithms that may automate the process in the near future. Although much emphasis is laid on one specific genre, Fizek's aim is to provide directions for further discussion and conceptualize the automation of play within the wider theme of the human-machine relationship and the automation of the everyday.

\section{Keywords}

automation, automation of play, algorithmic players, crowdsourcing games, humans and machines, artificial intelligence

43 A. Dippel, S. Fizek Playbouring Cyborgs: Renegotiating the Human-Machine Ensembles, prezentacja konferencyjna, Annual Meeting of the Association of American Geographers (AAG), sesja: Digital / Human / Labour, Boston 8.04.2017.

D. Haraway A Cyborg Manifesto... 